\title{
Development and Validation of High Performance Thin Layer Chromatography for the Determination of Ambrisentan in Bulk and Pharmaceutical Dosage Form
}

\section{Tauseef A Shaikh, Saurabh C Khadse, Vijendra P Rathod, Rahul Wani and Pritam S Jain*}

R. C. Patel Institute of Pharmaceutical Education and Research, Karwand Naka, India

*Corresponding Author: Pritam Jain, Professor, Department of Pharmaceutical Chemistry, R. C. Patel Institute of Pharmaceutical Education and Research, Karwand Naka, India.

Received: April 09, 2019; Published: May 17, 2019

DOI: $10.31080 /$ ASPS.2019.03.0285

\begin{abstract}
A simple, precise, sensitive and accurate high performance thin layer chromatography method for the determination of ambrisentan in bulk and in pharmaceutical dosage form was developed and validated. HPTLC separation was performed on aluminum plates precoated with silica gel $60 \mathrm{~F} 254(10 \times 10)$ as the stationary phase and mobile phase optimized as toluene: methanol $(3.5: 1.5 \mathrm{v} / \mathrm{v})$. The method was found to give a compact spot for ambrisentan at retention factor (RF) value $0.48 \pm 0.02$. Densitometric scanning was Performed at $263 \mathrm{~nm}$ respectively. Accuracy for the marketed formulation endobloc was found to be 99.75-101.69\% the proposed HPTLC method can routinely be used for determination of ambrisentan in bulk and Pharmaceutical dosage form.
\end{abstract}

Keywords: Ambrisentan; HPTLC; Development and Validation

\section{Introduction}

Ambrisentan chemically is (+)-(2S)-2-[(4,6-dimethylpyrimidin2-yl) 0xy] -3-methoxy-3, 3-diphenylpropanoic acid (figure 1), having molecular formula: $\mathrm{C}_{22} \mathrm{H}_{22} \mathrm{~N}_{2} \mathrm{O}_{4}$, with molecular weight $378.421 \mathrm{~g} / \mathrm{mol}$ [1]. Ambrisentan is an orally active selective type an endothelin receptor antagonist. It is used in the treatment of pulmonary hypertension [2]. Various analytical methods reported in literature survey for the estimation of ambrisentan. Such as, extractive spectrophotometric determination of ambrisentan [3]. Spectrophotometric Methods for the determination of ambrisentan using charge transfers reagents [4]. UV-visible spectrophotometric and RP-HPLC method development [5]. LC-ESI-MS/MS method for quantification of ambrisentan in plasma [6]. Simple validated RP-HPLC method for estimation of ambrisentan [7,8]. Stability indicating RP-HPLC methods for determination of ambrisentan and tadalafil [9]. Validated stability indicating high performance liquid chromatographic methods for the determination of ambrisentan $[10,11]$, has been found in literature. However, HPTLC method is not reported for the determination of ambrisentan in bulk and pharmaceutical dosage form. So, the objective of the present study is to develop simple, precise, sensitive and accurate HPTLC method for the determination of ambrisentan in bulk and pharmaceutical dosage form.

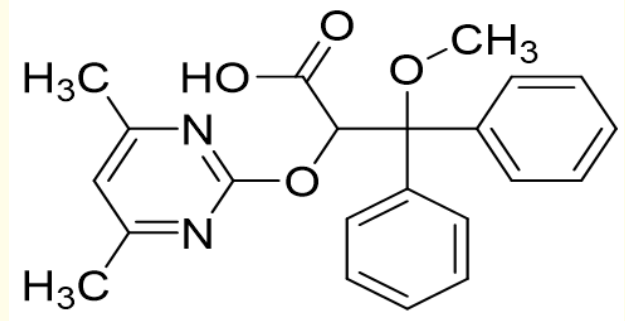

Figure 1: Structure of Ambrisentan.

\section{Experimental}

Chemical, reagent and solutions

Ambrisentan was obtained as a gift sample from Cipla pharmaceutical Ltd., Patalganga Mumbai. The commercial tablet dosage form of endobloc containing $10 \mathrm{mg}$ of ambrisentan manufactured by Cipla Ltd., Mumbai was procured from local market. Methanol purchased from Merck Ltd., Worli, Mumbai, India. 
Development and Validation of High Performance Thin Layer Chromatography for the Determination of Ambrisentan in Bulk and Pharmaceutical Dosage Form

\section{Chromatographic Condition and instrumentation}

The sample was spotted in the form of band $6 \mathrm{~mm}$ with a camag micro liter syringe on precoated silica gel aluminum plate $60 \mathrm{~F} 254$ (20 cm $\times 10 \mathrm{~cm}$ with $0.2 \mathrm{~mm}$ thickness, E. Merck, Germany) using a Camag Linomat 5 (Switzerland). The plates were brainwashed with methanol and activated at $110^{\circ}$ for $5 \mathrm{~min}$, prior to chromatography. The mobile phase consists of toluene: methanol (3.5:1.5 $\mathrm{v} / \mathrm{v}$ ). Linear ascends development was carried out in $10 \times 10 \mathrm{~cm}$ twin trough glass chamber. The optimized mobile phase chamber saturation time was $20 \mathrm{~min}$, at room temperature $\left(25 \pm 2^{\circ}\right)$ and relative humidity $(60 \pm 5 \%)$ and development distance was $80 \mathrm{~mm}$; the TLC plate was dried in a current of air dryer. Densitometric scanning was performed on a camag TLC scanner 3 equipped to win a CATS software version 1.3.0. At $263 \mathrm{~nm}$. The source of radiation utilized was deuterium lamp.

Preparation of standard solution and linearity study

Standard solution was prepared by accurately weighed 10 $\mathrm{mg}$ of ambrisentan powder and transferred in $10 \mathrm{ml}$ volumetric flask containing 5 methanol and volume was adjusted to mark with same solvent to get a concentration of $1000 \mu \mathrm{g} / \mathrm{ml}$. From this 0.6-3.6 $\mu \mathrm{l}$ of the solution were applied on TLC plate to obtain concentration of $300,600,900,1200,1500$ and 1800 ng per spot of ambrisentan, respectively. The calibration curve was plotting by area versus drug quantity per band. Calibration equations were determined by use of linear regression analysis and correlation coefficients $\left(\mathrm{r}^{2}\right)$ were calculated (Figure 2). Linearity studies results reported in Table 1.

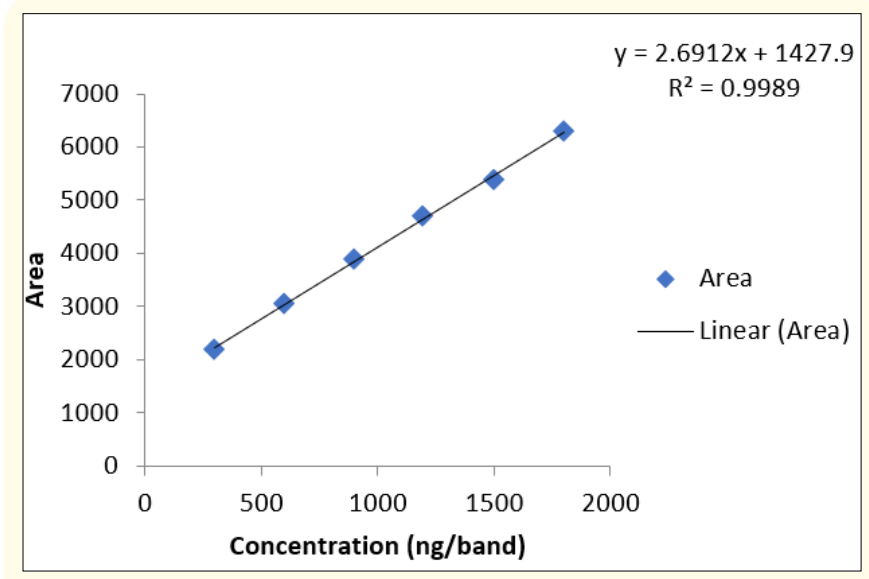

Figure 2: Calibration curve of Ambrisentan.

\begin{tabular}{|l|c|c|}
\hline $\begin{array}{c}\text { Concentration } \\
\text { (ng/band) }\end{array}$ & $\begin{array}{c}\text { Peak area } \\
\text { mean } \pm \text { SD }\end{array}$ & \%RSD \\
\hline 300 & $2194.4 \pm 7.54$ & 0.34 \\
\hline 600 & $3058.4 \pm 20.49$ & 0.67 \\
\hline 900 & $3888.3 \pm 69.65$ & 1.79 \\
\hline 1200 & $4716.2 \pm 35.33$ & 0.74 \\
\hline 1500 & $5388 \pm 25.05$ & 0.46 \\
\hline 1800 & $6279.5 \pm 51.42$ & 0.81 \\
\hline
\end{tabular}

Table 1: Result of Linearity Study.

\section{Analysis of tablet formulation}

Twenty tablets were accurately weighed and powdered. An amount of powdered drug equivalent to $10 \mathrm{mg}$ of ambrisentan was transferred to $10 \mathrm{ml}$ volumetric flask containing $7 \mathrm{ml}$ methanol and sonicated for $20 \mathrm{~min}$. volumetric flask shakes manually for $10 \mathrm{~min}$; volume was made up to the mark using same solvent. The standard solution was then filtered through Whatman filter paper no. 41 giving concentration of stock solution $1000 \mu \mathrm{g} / \mathrm{ml}$. Concentrations of $900 \mathrm{ng} /$ band of ambrisentan were spotted on HPTLC plates. The plates were developed and scanned. The concentrations of the drug were assessed from the linearity curves (Figure 3 ). The results are depicted in Table 2.

\begin{tabular}{|c|c|c|}
\hline $\begin{array}{c}\text { Concentration } \\
\text { (ng/band) }\end{array}$ & $\begin{array}{c}\text { Amount found } \\
\text { (ng/band) }\end{array}$ & $\begin{array}{c}\text { \% Amount } \\
\text { found }\end{array}$ \\
\hline 900 & 903.64 & 100.40 \\
\hline 900 & 916.16 & 101.79 \\
\hline 900 & 880.63 & 97.84 \\
\hline 900 & 890.82 & 98.98 \\
\hline 900 & 906.39 & 100.71 \\
\hline 900 & 909.62 & 101.06 \\
\hline
\end{tabular}

Table 2: Result of Analysis of Tablet formulation.

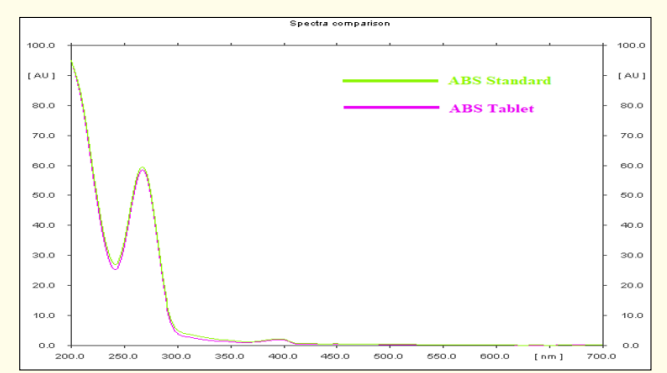

Figure 3: The peak purity spectra of Ambrisentan standard and Ambrisentan extracted from tablet, scanned at peak-start, peak- apex and peak- end position of the band. 


\section{Method Validation}

\section{Precision}

The precision of the proposed method was ascertained by actual determination of three replicates of 600,900 and $1200 \mathrm{ng} /$ band concentration of ambrisentan was applied precoated silica gel aluminum plate. It was studied in terms of intra and inter-day variations.

\section{Recovery Studies}

Recovery studies was executed by applying the method to drug samples, in which known amount of ambrisentan at 80\%, 100\% and $120 \%$ was added to a pre-quantified sample solution.

\section{Robustness}

To determine the robustness of the purposed method, the experimental condition was deliberately changed such as mobile phase composition, duration of chamber saturation, development distance.

\section{Ruggedness}

This parameter of the method was evaluated by two analysts using same environmental and experimental conditions.

\section{Detection of limit and quantification of limit}

The detection of limit (DL) and quantification of limit (QL) of the drug (ambrisentan) were calculated by using the equations.

$\mathrm{DL}=3.3 \times \sigma / \mathrm{S}$

$\mathrm{QL}=10 \times \sigma / \mathrm{S}$

\section{Specificity}

The peak purity of ambrisentan was assessed by correlating the spectra of ambrisentan extracted from tablets and ambrisentan standard.

\section{Result and Discussion}

\section{HPTLC method development and optimization}

In this study, determination of ambrisentan in bulk and pharmaceutical dosage form was performed by HPLTC method. TLC procedure was first optimized normal-phase HPTLC on silica gel 60 F254 with various ratios of methanol, toluene were used as mobile phase, but, tailing observed to overcome the problem, methanol: toluene $(1.5: 3.5 \mathrm{v} / \mathrm{v})$ was used and the result is a good resolution and sharp peak with $\mathrm{Rf}$ (retention factor) value of 0.48 \pm 0.02 for ambrisentan (Figure 4). 3-D linearity chromatogram of Ambrisentan (Figure 5).

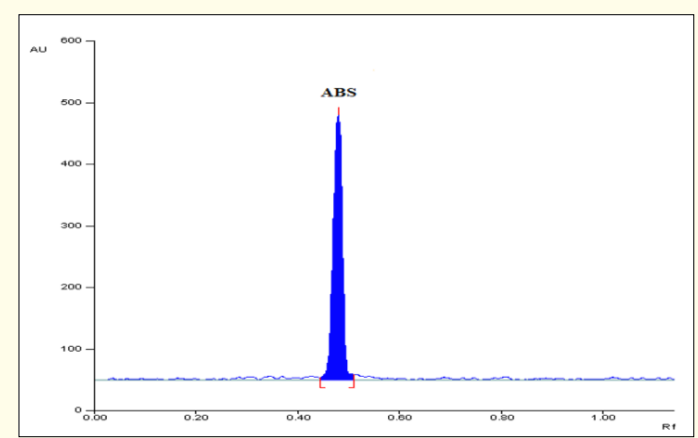

Figure 4: Typical HPTLC chromatogram of ambrisentan $(\mathrm{Rf}=0.48)$.

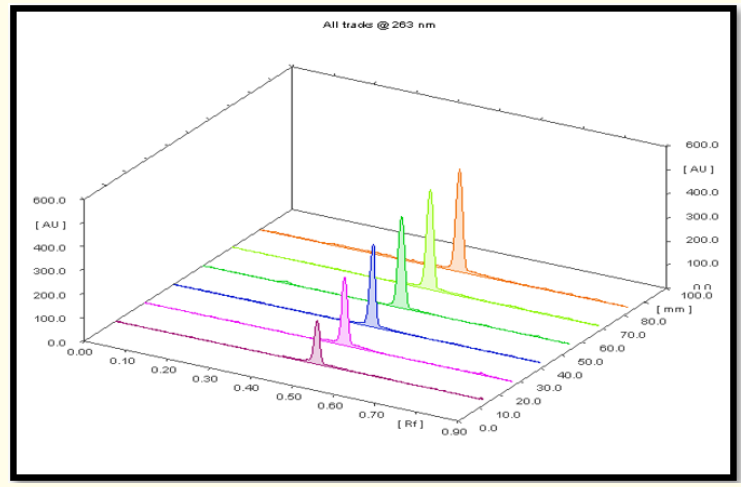

Figure 5: 3-D linearity chromatogram of Ambrisentan.

\section{Validation of method}

The method was validated with respect to various parameters including linearity, limit of detection, and quantification of limit, precision, ruggedness and accuracy according to ICH guidelines.

\section{Precision}

Precision of the method was studied as repeatability and intraday and an inter-day variation was found to be less than 2 shown in table 3 . 
Development and Validation of High Performance Thin Layer Chromatography for the Determination of Ambrisentan in Bulk and Pharmaceutical Dosage Form

\begin{tabular}{|c|c|c|}
\hline $\begin{array}{c}\text { Concentration } \\
\text { (ng/band) }\end{array}$ & $\begin{array}{c}\text { Amount found } \\
\text { (ng/band) } \pm \text { SD (n=3) }\end{array}$ & \%RSD \\
\hline Intra-day precision & & \\
\hline 600 & $602.99 \pm 4.91$ & 0.81 \\
\hline 900 & $891.59 \pm 9.30$ & 1.04 \\
\hline 1200 & $1202.98 \pm 9.60$ & 0.79 \\
\hline Inter-day precision & & \\
\hline 600 & $599.52 \pm 3.80$ & 0.63 \\
\hline 900 & $890.90 \pm 7.37$ & 0.82 \\
\hline 1200 & $1204 \pm 6.29$ & 0.52 \\
\hline
\end{tabular}

Table 3: Result of Precision study.

n-number of determinations

\section{Recovery}

Recovery experimental was performed at three different levels i.e. 80,100 and $120 \%$. To the pre-analyzed sample solutions, a known amount of mixed drug standard solution The purposed method when used for determination of ambrisentan from a known amount of mixed drug standard solution of were spotted at three different levels The chromatogram was developed and scanned as described above; the results of \% recovery are shown in table 4.

\begin{tabular}{|c|c|c|c|c|c|}
\hline Drug & $\begin{array}{c}\text { Initial } \\
\text { Amount } \\
\text { (ng/ } \\
\text { band) }\end{array}$ & $\begin{array}{c}\text { Amount } \\
\text { added } \\
\text { (ng/ } \\
\text { band) }\end{array}$ & $\begin{array}{c}\text { Amount } \\
\text { Recovered } \\
\text { (ng/band) }\end{array}$ & $\begin{array}{c}\text { \% Recovery } \\
\text { (n=3) }\end{array}$ & $\begin{array}{c}\text { \% } \\
\text { RSD }\end{array}$ \\
\hline & 600 & 480 & 1082.53 & 100.52 & 1.36 \\
\hline ABS & 600 & 600 & 1198.53 & 99.75 & 0.38 \\
\hline & 600 & 720 & 1332.21 & 101.69 & 1.45 \\
\hline
\end{tabular}

Table 4: Result of Recovery study. n-number of determinations

\section{Robustness}

Robustness was studied in six replicate at the concentration $900 \mathrm{ng} / \mathrm{band}$ of ambrisentan. In this experiment, three parameters (mobile phase composition, mobile phase, development distance, duration of saturation) were studied; the results are shown in table 5 .

\section{Ruggedness}

Ruggedness of the proposed method was studied by two different analysts using the same experiment and environmental conditions. The band $900 \mathrm{ng} / \mathrm{band}$ of ambrisentan were applied on RP-HPTLC plates. Results shown in table 6.

\begin{tabular}{|c|c|c|c|}
\hline Sr. no. & Parameters & $\begin{array}{c}\text { + S.D. of peak } \\
\text { Area }\end{array}$ & $\begin{array}{c}\text { \% R.S.D. } \\
{[\mathbf{n}=6]}\end{array}$ \\
\hline 1 & $\begin{array}{c}\text { Mobile phase } \\
\text { composition }\end{array}$ & & \\
\hline & $3: 2 v / v$ & 39.16 & 1.01 \\
\hline & $4: 1 \mathrm{v} / v$ & 48.31 & 1.26 \\
\hline 2 & $\begin{array}{c}\text { Development } \\
\text { distance }\end{array}$ & & \\
\hline & 75 mm & 41.60 & 1.71 \\
\hline 3 & 85 mm & 62.64 & 1.62 \\
\hline & $\begin{array}{c}\text { Duration of } \\
\text { saturation }\end{array}$ & & \\
\hline & 15 min & 36.11 & 0.94 \\
\hline & 25 min & 43.78 & 1.64 \\
\hline
\end{tabular}

Table 5: Result of Robustness study. n-number of determinations

\begin{tabular}{|c|c|c|c|}
\hline \multirow[b]{2}{*}{ Drug } & \multirow{2}{*}{$\begin{array}{c}\text { Concentration } \\
\text { (ng/band) }\end{array}$} & \multicolumn{2}{|c|}{ Amount Found (\%) \pm S.D. } \\
\hline & & $\begin{array}{c}\text { Analysts- I } \\
(n=6)\end{array}$ & $\begin{array}{c}\text { Analysts- II } \\
(n=6)\end{array}$ \\
\hline Ambrisentan & 900 & $99.19 \pm 0.90$ & $99.66 \pm 0.20$ \\
\hline
\end{tabular}

Table 6: Result of Ruggedness study. n-number of determinations

Sensitivity

The sensitivity of proposed methods was estimated in terms of Detection of Limit (LOD) and Quantification of Limit (LOQ). The LOD and LOQ were calculated using equation LOD $=3.3 \mathrm{X}$ N/B and $\mathrm{LOQ}=10 \mathrm{XN} / \mathrm{B}$; where, ' $\mathrm{N}$ ' is standard deviation of the peak areas of the drugs ( $n=3$ ), taken as a measure of noise, and 'B' is the slope of the corresponding calibration curve. Ambrisentan solutions of 300, 350, 400,450, 500 and $600 \mathrm{ng} /$ band were applied on HPTLC plates developed and scanned. The LOD and LOQ values found were $13.63 \mathrm{ng}$ and $41.30 \mathrm{ng}$, respectively.

\section{Specificity}

The peak purity of ambrisentan was determined by comparison with the spectra at peak start, peak apex and peak end position of the spot. $\mathrm{r}^{2}[\mathrm{~S}, \mathrm{M}]=0.9998$, and $\mathrm{r}^{2}[\mathrm{M}, \mathrm{E}]=0.9987$. Good correlation $\left(r^{2}=0.9989\right)$. The peak purity spectra were shown in Figure. 


\section{Conclusion}

The proposed HPTLC method has been developed successfully and validated for the determination of drug (ambrisentan) in pharmaceutical dosage form. The results indicated that the developed methods were precise, accurate, sensitive and robust. Hence, the developed HPTLC method is suitable for routine determination in commercial tablet.

\section{Acknowledgment}

Authors are thankful to Dr. S. J. Surana, Principal of R. C. Patel Institute of Pharmaceutical Education and Research, Shirpur, Dist: Dhule (MS), for providing necessary laboratory facility.

\section{Bibliography}

1. Merck and Co., The Merck index. $14^{\text {th }}$ Edition, Whitehouse station, NJ, USP, an Encyclopedia of chemical. Drugs an biological 65 (2006).

2. AJ Peacock., et al. "Ambrisentan for the treatment of adults with pulmonary arterial hypertension a review". Current Medical Research and Opinion 31.9 (2015): 1793-1807.

3. NS Kumar., et al. "Extractive spectrophotometric Determination of ambrisentan" Advanced Pharmaceutical Bulletin 3.1 (2013): 231-237.

4. CB Venkata and SC Ball. "Spectrophotometrc Methods for the Determination of Ambrisentan Using Charge Transfer Reagents". Journal of Applied Chemical Research 7.3 (2013): 7-14.

5. RK Singla and BR Chandu. "Design of Experimental Assisted UV-Visible Specrotrophotometric and RP-HPLC method development for ambrisentan estimation in bulk and formulation". World Journal of Analytical Chemistry 2.2 (2014): 23-30.

6. RNirogi., et al. "LC-ESI-MS/MS method for quantification for ambrisentan in plasma and application to rat pharmacokinetic study, Biomed". Journal of Chromatography 26.10 (2012): 1150-1156.
7. RKarthikeyan., et al. "Simple validated RP-HPLC method for estimation of ambrisentan in pharmaceutical dosage form". International Bulletin of Drug Research 5.9 (2015): 1-18.

8. M.Balakrisna., et al. "RP-HPLC-PDA method for the analysis of ambrisentan bulk and pharmaceutical dosage form". International Journal of Chemistry and Pharmaceutical Sciences 4.4 (2013): 45-50.

9. JK Patel and NK Patel. "Stability indicating RP-HPLC method for the determination of ambrisentan and tadalafil in pharmaceutical dosage form". Scientia Pharmaceutica 82.4 (2014): 759-764.

10. BS Seshamamba., et al. "Validated stability indicating High performance liquid chromatographic for the determination of ambrisentan in pharmaceutical dosage form". Journal of Pharmaceutical Sciences 19.4 (2014): 109-115.

11. MBV Narayana., et al. "Validated Specific stability-indicating RP-HPLC assay method for ambrisentan and its related substance". Journal of Chromatographic Science 52.8 (2013): 818-825.

Volume 3 Issue 6 June 2019 (C) All rights are reserved by Pritam S Jain., et al. 